Migration Studies - Review of Polish Diaspora nr 1 (175)/2020, http://www.ejournals.eu/Studia-Migracyjne/ DOI: 10.4467/25444972SMPP.20.004.11795

\title{
The development of the European Union in the areas of migration, visa and asylum after 2015. Priorities, effects, perspectives
}

\author{
KATARZYNA CYMBRANOWICZ1 \\ Department of European Studies and Economic Integration, Cracow University of Economics
}

The article entitled 'The development of the European Union in the areas of migration, visa and asylum after 2015. Priorities, effects, perspectives' is a contribution to the public discourse on one of the biggest problems and challenges facing the European Union in the 21 st century from a political, economic and social perspective. The (un)controlled influx of refugees to Europe after 2015, which is the result of political destabilization and the unstable socio-economic situation in the region of North Africa and the Middle East, clearly indicates that during the 'test', the existing refugee protection system in the European Union did not pass the 'exam'. In connection with the above, attempts to modify it have been made at the EU level. This article is a presentation of individual solutions ('Fortress Europe', 'Open Door Policy', 'Sluice'), as well as an analysis and evaluation of the possibilities of their implementation in the current difficult crisis conditions.

Keywords: migrant, refugee, migration crisis, the European Union

\section{Introduction}

Recent years have seen the largest wave of migration from North Africa and the Middle East towards Europe ${ }^{2}$ since the end of World War II. The massive and uncontrolled influx of migrants to Europe has resulted in a crisis which became the greatest challenge faced by the European Union (EU) in the second decade of the 21 st century.

1 Contact: cymbrank@uek.krakow.pl

2 Its causes are primarily seen in the process of political destabilization in the region (Syria, Libya, Sudan, South Sudan, Eritrea, Nigeria, Afghanistan), the creation and activity of Daesh - Islamic State, or the unstable socio-economic situation resulting from the so-called Arab Spring.

Please cite as: Cymbranowicz K. (2020), The development of the European Union in the areas of migration, visa and asylum after 2015. Priorities, effects, perspectives, "Studia Migracyjne - Przegląd Polonijny", 1 (175), pp. 67-95. DOI 10.4467/2544497 2SMPP.20.004.11795 
A lively discussion concerning this problem at both the transnational and national levels shows that, since 2015, successive waves of migration caused not only the crisis in the EU, but also a crisis of the EU as an international organization reflecting the idea of community of nations and European values ${ }^{3}$. This situation has shown the lack of effective EU migration, visa and asylum policies, combined with ineffective management mechanisms in the extraordinary situation that was (and still is) posed by migratory pressure. Therefore, the migration crisis is regarded as another factor destabilizing the process of European integration and weakening the Union on the international stage. After the financial and economic problems of 2008-2010, and the (un)expected result of the referendum in the UK from June 2016 concerning Brexit, it should be listed as among the most important international events affecting the functioning of the EU4 ${ }^{4}$.

The answer to the question of EU policy towards arriving migrants and refugees is best reflected by the words of the former President of the European Commission - Jean-Claude Juncker, who stated: '(...) migration must stay on our radar. In spite of the debate and controversy around this topic, we have managed to make solid progress - though admittedly insufficient in many areas (...). Europe, contrary to what some say, is not a fortress and must never become one. Europe is and must remain the continent of solidarity where those fleeing persecution can find refuge ${ }^{\prime 5}$. There can be no doubt that this crisis requires fast, decisive, wise and thought-out action from the EU and its Member States. In the first few months of the crisis, decisions regarding migration and asylum were made under the pressure of the 'moment'. It turned out that the EU had neither an anti-crisis strategy nor a strategy for migration, visa and asylum policies that would match the problems and challenges of the 21 st century.

The aim of the article is to analyze and evaluate actions taken at the European level by EU institutions and EU Member States in the field of migration, visas and asylum after the outbreak of the crisis in 2015. The research questions concern the approach of the EU and its Member States to possible actions aimed at solving or limiting the migration and refugee crisis (proposals, mechanisms, tools, measures). The article is based on available sources dealing with the problem of migration and

${ }^{3}$ For more about the EU crisis and the crisis in EU, including the situation resulting from the influx of over 1.8 million people from North Africa and the Middle East into the EU in 2015, see: E. Collett, C. Le Coz (2018), After the Storm: Learning from the EU response to the migration crisis, Brussels: Migration Policy Institute Europe; P. Maldini, M. Takahashi (2017), Refugee Crisis and the European Union: Do the Failed Migration and Asylum Policies Indicate a Political and Structural Crisis of European Integration?, 'Communication Management Review', No. 2, pp. 54-72; H. Tendera-Właszczuk (2017), Kryzys migracyjny zagrożeniem dla zasad i podstawowych wartości Unii Europejskiej, in: Tendera-Właszczuk, H., Bąba, W., Zajączkowska, M. (eds.), Nowe perspektywy integracji europejskiej w obliczu wyzwań i zagrożeń, Warszawa: Difin, pp. 32-47.

${ }^{4}$ More: World Economic Forum (2016), The Global Risks Report 2016. 11th Edition, http://www3. weforum.org/docs/GRR/WEF_GRR16.pdf [Accessed: 15.08.2018].

${ }^{5}$ EC (2017), President Jean-Claude Juncker's State of the Union Address 2017, http://europa.eu/ 


\section{SM̂PP}

refugees in Europe in the context of the crisis faced by the Union. An interdisciplinary approach to the studied phenomenon has compelled the use of various research methods, including institutional, legal, decision-making, comparative and source material analysis.

\section{European Union policies towards migrants - the issue of asylum and refugee}

Migration, including the matters of asylum and refugees, is problematic because, as a global issue, it is reflected in international, EU and national law. Hence, the often different terminology may result from the fact that certain terms are defined differently in international, EU or national law. From the perspective of a country that accepts migrants, the distinction between who is a migrant and who is a refugee is important. The whole difficulty lies in the fact that the term 'migrant', as opposed to the term 'refugee', is not regulated under international but national law - it is subject to a different regime and different legal protections. According to the Geneva Convention of 1951 and the Protocol to the Geneva Convention of 1967, a refugee is a person who 'owing to wellfounded fear of being persecuted for reasons of race, religion, nationality, membership of a particular social group or political opinion, is outside the country of his nationality and is unable or, owing to such fear, is unwilling to avail himself of the protection of that country; or who, not having a nationality and being outside the country of his former habitual residence as a result of such events, is unable or, owing to such fear, is unwilling to return to it' ${ }^{\prime 6}$. From this provision it can be concluded that people who left their country motivated by other reasons are not treated as 'refugees' or asylum seekers ${ }^{7}$, but as 'migrants'. These people deserve to be protected and to have their basic needs met, but under international human rights law'.

The issue of asylum and refugee in the Communities, and currently in the European Union, is included in the cooperation of the Member States in the field of migration, visas and asylum, which in turn is closely linked to the development

6 United Nations, Convention relating to the Status of Refugees. Geneva. 28 July 1951, https:// treaties.un.org/doc/Treaties/1954/04/19540422\%2000-23\%20AM/Ch_ V_2p.pdf [Accessed: 15.08.2018].

7 An asylum seeker is a person who wants to be recognized as a refugee but is still waiting for the decision to grant them this status. If an asylum seeker is refused refugee status, they must leave the country of destination, unless are given permission to remain there on the basis of other humanitarian measures. More: T. Reitano, L. Adal, M. Shaw (2014), Smuggled Futures: The dangerous path of the migrant from Africa to Europe, The Global Initiative against Transnational Organized Crime, http://www. integrazionemigranti.gov.it/Attualita/Notizie/Documents/Global\%20Initiative.pdf [Accessed: 4.08.2018].

${ }^{8}$ For example, the Universal Declaration of Human Rights, the International Covenant on Civil and Political Rights and the International Covenant on Economic, Social and Cultural Rights, as well as other important international and regional treaties recognize that human rights are vested in everyone, including migrants and refugees. 
of cooperation in the field of home affairs and justice. The issues of asylum and refugees only appeared sporadically on the Community agenda - initially they were not an important element of joint activities, and it was only with the development of integration processes that they gained more importance.

The first timid attempts to strengthen political cooperation in the field of asylum and refugees were taken in the mid-1950s, but the provisions adopted in the Treaties of Rome (1957) did not anticipate any far-reaching actions in the area of harmonization or communitarisation. Strengthening the cooperation between Member States due to the implementation of the assumptions aimed at establishing a single internal market by the end of 1992 was a breakthrough in the development of migration, visa and asylum policies. The so-called Schengen Agreements ${ }^{9}$, the White Paper on the creation of a single internal market and the Single European Act were the most important projects aimed at achieving this goal. The provisions contained in these documents were meant to create systemic solutions, according to which in the territory of the signatory states, free movement of people would be ensured, while maintaining all safety rules. The main 'pillars' of the Schengen Agreements (abolition of controls at internal borders, implementation of a common visa, asylum and duty policies), were based on the liberalization and harmonization of regulations regarding the border crossing of the signatory states by both people and goods. Undertaking actions leading to the abolition of border checks and simplification of duty control on internal borders were simultaneously related to:

- tightening border controls and visa policy towards non-EU citizens at external borders;

- unification of the right to asylum and determination of the competence of one country to examine the application for asylum;

- running a common internal security policy, based on close cooperation between border, duty, police and judicial services ${ }^{10}$;

9 The Schengen agreements are made up of: Schengen Agreement (so-called Schengen I), which concerns the gradual abolition of checks at common borders signed on June 14, 1985 in the Schengen city in Luxembourg by 5 Member States of the then EC, ie Belgium, Germany, France, Luxembourg and the Netherlands; Convention Implementing the Schengen Agreement (so-called Schengen II), which concerns the rules for the implementation of the provisions of the Schengen Agreement signed on 19 June 1990 by the above-mentioned countries. The Schengen acquis was incorporated into the acquis communautaire as a result of the Treaty of Amsterdam on October 2, 1997. The Treaty came into force less than two years later, ie on May 1, 1999 - from now on decisions regarding the Schengen area are taken at a supranational level as part of institutional and legal systems of the European Union.

10 On 15.3.2006, the Council adopted the so-called Schengen Borders Code, which regulated issues related to the temporary restoration of border controls at the internal borders of the Schengen area. The aforementioned regulation (EC) No 562/2006 of the European Parliament and of the Council of 15 March 2006 establishing a Community Code on the rules governing the movement of persons across borders (Schengen Borders Code) was significantly changed several times, and finally replaced by regulation (EU) 2016/399 of the European Parliament and of the Council of 9 March 2016 on a Union Code on the rules governing the movement of persons across borders (Schengen Borders Code). 


\section{SM̂PP}

- the creation of a common Schengen Information System (SIS), which would contain information about persons and objects important to each signatory from the point of view of controlling population movement (mainly concerning foreigners) and security policy.

The solutions adopted under the Schengen Agreements gave rise to a jointly supervised and uniform policy on migration. Additionally, at the same time, the European Commission announced a White Paper on the creation of a single internal market. This document anticipated the introduction of a common visa policy in 1990 and a common extradition policy in 1991. On the other hand, the Single European Act of 1986, constituting the revision of the Roman Treaties, introduced, among others, the principle of free movement of persons, which was of considerable importance for the functioning of the EC and pursuing a common policy towards persons seeking international protection.

As mentioned earlier, Community policies in the field of migration, visas and asylum were not carried out until the Maastricht Treaty. From November 1, 1993, issues of migration and related problems were covered by the common interest ${ }^{11}$. The solutions adopted in Maastricht were aimed at organizing, formalizing and improving the cooperation of Member States in these areas. It was the first important step towards giving the policies on migration, visas and asylum a transnational character.

An important step in the development of migration, visa and asylum policies was the Treaty of Amsterdam. Since May 1, 1999, regulations regarding migration, visa and asylum policies and the acquis of Schengen have been included in the acquis communautaire. The 'communitarisation' of these areas, and thus their transfer from the intergovernmental area (the third pillar) to the community sphere (I pillar), was a breakthrough in the shaping of migration, visa and asylum policies at the supranational level within the EU structures.

In the years 1999-2002, during the next European Council summits in Tampere, Laeken and Seville, the Heads of State and Government of the Member States worked on the AFSJ program outlined in Maastricht and Amsterdam. These activities aimed at the total 'communitarisation' of migration, visa and asylum policies and the creation of a common asylum system, so that refugees residing in the EU would have the same level of protection - equal rights and obligations, both for those applying for international protection, as well as the host country ${ }^{12}$.

The culmination of the process begun in Amsterdam was the adoption of the Lisbon Treaty in 2007. The amended Treaty on European Union (TEU) and the Treaty on the Functioning of the European Union (TFEU), orders and specifies the hitherto

11 The cooperation of Member States had been limited up to this point - it only amounted to joint initiatives undertaken to solve specific problems. With time, this proved inadequate and eventually led to the creation of a cooperation field on the EU level in the 1990s.

12 Each EU Member State must meet the minimum legal standards corresponding to the regulations of the Convention on the Status of Refugees drafted in Geneva on 28.7.1951 (the so-called Geneva Convention). 
adopted and functioning mechanisms falling within the scope of the Area of Freedom, Security and Justice (CFSP), giving them a communal character ${ }^{13}$. However, as the practice has shown, the changes introduced have not contributed to the revival of cooperation between Member States in the shaping of common migration, visa and asylum policies. The lack of cooperation became visible with the outbreak of the migration and refugee crisis in 2015, when it turned out that the treaty provisions in this area were not aligned with the political reality.

In addition to the changes brought by successive revision treaties, EU institutions (including primarily the European Commission in cyclical announcements issued during the last few years) indicate that the most significant undertakings in the field of migration, visa and asylum policies until 2015 were:

- The Dublin II Regulation establishing criteria and mechanisms for determining the Member State's responsibility for examining an asylum application (2003) and Dublin III, setting criteria and mechanisms for determining the Member State responsible for examining the application for international protection filed in one of the Member States by a third-country national or stateless person (2013); both regulations replaced the regulations of 1990 known under the name of the Dublin Convention,

- The Hague Program of 2004 (applicable in 2004-2009),

- European Pact on Immigration and Asylum from 2008,

- The Stockholm program. An open and secure Europe for the well-being and protection of citizens from 2009 (applicable in 2010-2014),

- A global approach to migration and mobility issues from 2011.

Cooperation between Member States in the areas of migration, visas and asylum has never been free of various barriers. They were related to political, legal and ideological factors ${ }^{14}$. As a rule, no one questioned the very need to establish a policy in this particularly difficult and controversial area, but often the actions undertaken (or, on the contrary, inactions) by the Member States slowed down this process ${ }^{15}$. It seemed that the trend of moving from intergovernmental to supranational forms of cooperation, observed after the Amsterdam reform (and after 10 years strengthened by the Lisbon reform), will continue. However, it turned out quite differently - the series of crises that have recently reached the EU have caused a retreat from this trend and thus put the Member States to the test.

${ }^{13}$ According to the current acquis communautaire, the EU in the field of AFSJ has shared competences (art. 4 TFEU), which means that both the EU and the Member States can make laws and adopt binding legal acts. This is important for the effective implementation of activities in the discussed area.

14 More: J. Szymańska (2016), Międzyrządowość vs. ponadnarodowość w polityce migracyjnej i obszarze spraw wewnętrznych Unii Europejskiej, in: Grosse, T. G. (ed.), Polityki europejskie w dobie kryzysu, Warszawa: Wydawnictwo Naukowe SCHOLAR, pp. 253-274.

15 It is enough to recall the Schengen case - the establishment of the Schengen system took place outside the Community framework, only with time it was included in the EU structures and its acquis. 


\section{SM̂PP}

\section{An unfavorable atmosphere around the problem of migration - political and social attitudes in times of crisis}

The issue of migration has dominated the public debate in many European countries in recent years. Undoubtedly, public opinion on migration is an important determinant of policy development in this area, both in the Member States (national policy) and in the EU (AFSJ). Therefore, it is worth looking at the available research in this field from the period of the largest exodus to Europe in the 21 st century ${ }^{16}$. It turns out that for several years terrorism and immigration occupy the first two places on the list of Europeans' worries - respectively 44 per cent and 38 per cent of them considered that those are the biggest challenges for the Union. As for migration, as many as 68 per cent of Europeans are in favor of a common European migration policy (a decrease of 1 pp from autumn 2016). In 27 Member States, a majority of respondents support 'a common European policy on migration' (up from 26 in autumn 2016), with the highest scores in Spain (86 per cent), the Netherlands (84 per cent), Germany (83 per cent), and Luxembourg and Cyprus (both 80 per cent). At the other end of the scale, support is more limited in Hungary (47 per cent vs. 45 per cent 'against'), Estonia (47 per cent vs. 43 per cent) and Poland (49 per cent vs. 42 per cent), while the Czech Republic is the only country where a majority of respondents oppose a common European migration policy (56 per cent 'against' vs. 39 per cent). According to research, Europeans are less concerned about the influx of people from other Member States than from outside the EU. In the spring of 2017, immigrants coming from another EU country generated positive associations in 63 per cent of respondents (an increase of 2 p.p. from the autumn of 2016), and negative in 30 per cent (a fall of 3 p.p. from the autumn of 2016). In the case of immigrants from third countries, the results were less optimistic. Only 38 per cent of Europeans declared a positive attitude towards non-EU immigrants (an increase of 1 p.p. from autumn 2016), while as many as 54 per cent expressed a negative one (a drop of 2 p.p. from autumn 2016). In the 22 EU Member States, a negative attitude on the part of the public towards immigrants from third countries prevailed (the exceptions were Ireland, Spain, Luxembourg, Portugal, Sweden and the UK) ${ }^{17}$.

Bearing public opinion in mind, it seems natural that the concerns about the problem of terrorism and immigration in Europe contribute to the propagation of

${ }^{16}$ More: P. Sasnal (2016), Exodus z Syrii. Migranci i uchodźcy z Bliskiego Wschodu, in: Kuźniar, R. (ed.), Rocznik Strategiczny 2015/16. Przegląd sytuacji politycznej, gospodarczej i wojskowej w środowisku międzynarodowym Polski, Warszawa: Wydawnictwo Naukowe SCHOLAR, pp. 336-356.

17 The standard Eurobarometer survey from the spring of 2017 was conducted in the form of direct interviews on 20-30.5.2017. A total of 33,180 people participated in the survey from all EU Member States and candidate countries. More: EC (2017b), Standard Eurobarometer 87 - Spring 2017. Public opinion in the European Union. First results, http://ec.europa.eu/commfrontoffice/publicopinionmobile/ index.cfm/Survey/getSurveyDetail/surveyKy/2142 [Accessed: 10.02.2018]. 
old stereotypes and the emergence of new ones in the public space. The Transatlantic Trends: Mobility, Migration and Integration report from 2014 shows that over 32 per cent of Europeans intuitively (without relying on official data) believe that there are too many immigrants in their country ${ }^{18}$. It is worth noting that these studies were carried out before the outbreak of the migration crisis. It can be assumed that, if repeated (after 2015), their results would be less optimistic. In the context of the unresolved crisis, it seems likely that the debate on immigrants and the 'problems' associated with them will continue to be the number one theme in Europe for a long time and it will certainly not be easy ${ }^{19}$.

\section{How to avert the crisis? Anti-crisis initiatives and scenarios for the development of EU migration, visas and asylum policies}

As H. Wyligała argues: 'Promoting peaceful solutions in conflict regions in Middle East and Africa, sending civil and military stabilization missions there and silencing disputes turned out to be insufficient to prevent the migration wave from $2015^{\prime 20}$. Problems began earlier, already in 2011, when there was a sudden increase in the number of immigrants to the EU stemming from the events of the Arab Spring.

Although the peak of the migration crisis has passed, from the European point of view this is not the end of the problem. On the one hand, a general downward trend can be observed, which is optimistic. However, on the other hand, it is alarming that immigrants have changed their routes (and there is still a high percentage of people who do not reach borders safely):

- illegal crossings are still most often detected on the so-called the Central Mediterranean route, however, its popularity is decreasing (in 2017 almost one third fewer migrants attempted this route than in 2014),

- a route that is gaining in popularity is the so-called the West Mediterranean route (in 2017, attempts at the illegal crossing of borders on this route more than tripled in comparison to 2014).

18 GMF (2014), Transatlantic Trends: Mobility, Migration and Integration. Key Findings from 2014 and Selected Highlights from Transatlantic Trends and Transatlantic Trends: Immigration 2008-2013, http://www.gmfus.org/publications/transatlantic-trends-mobility-migration-and-integration [Accessed: 10.08.2018].

19 More: J. Nakonieczna-Bartosiewicz (2016), Migracyjny szok czy migracyjna histeria?, in: Kuźniar, R. (ed.), Rocznik Strategiczny 2015/16. Przegląd sytuacji politycznej, gospodarczej i wojskowej w środowisku międzynarodowym Polski, Warszawa: Wydawnictwo Naukowe SCHOLAR, pp. 369-384.

20 H. Wyligała (2016), Strategiczny rozwój narzędzi polityki migracyjnej UE w obliczu kryzysu migracyjnego, „Rocznik Bezpieczeństwa Międzynarodowego” 10(2), pp. 163-189. 


\begin{tabular}{|c|c|c|c|c|c|c|c|c|c|c|c|}
\hline Together & $\begin{array}{l}\stackrel{\stackrel{n}{m}}{\stackrel{5}{5}} \\
\stackrel{\text { Ln }}{\leftarrow}\end{array}$ & \begin{tabular}{l} 
f \\
$\infty$ \\
\multirow{+}{+}{}
\end{tabular} & $\begin{array}{l}\infty \\
\circ \\
\wp \\
\wp \\
\wp\end{array}$ & 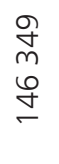 & $\begin{array}{l}\text { ñ } \\
\text { ñ } \\
\end{array}$ & \begin{tabular}{l}
$\bigcirc$ \\
$\infty$ \\
0 \\
0 \\
\hdashline
\end{tabular} & 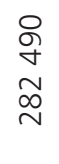 & 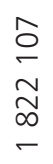 & 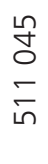 & $\begin{array}{l}\infty \\
\stackrel{\infty}{+}\end{array}$ & $\begin{array}{l}\infty \\
\stackrel{\infty}{+} \\
\stackrel{+}{\sim}\end{array}$ \\
\hline Eastern route & $\stackrel{\stackrel{n}{m}}{\stackrel{m}{-}}$ & $\begin{array}{l}\circ \\
\stackrel{ }{\circ} \\
-\end{array}$ & $\begin{array}{l}\text { 융 } \\
-\end{array}$ & $\begin{array}{l}\stackrel{0}{1} \\
\stackrel{0}{\circ} \\
-\end{array}$ & $\begin{array}{l}8 \\
8 \\
-\end{array}$ & 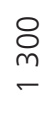 & 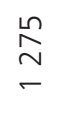 & ふૂ & $\begin{array}{l}\stackrel{g}{+} \\
\stackrel{m}{-}\end{array}$ & $\stackrel{\bullet}{\stackrel{0}{N}}$ & $\stackrel{*}{\stackrel{*}{\infty}_{\infty}}$ \\
\hline $\begin{array}{r}\text { West-African } \\
\text { route }\end{array}$ & $\begin{array}{l}\stackrel{8}{2} \\
\text { a }\end{array}$ & $\stackrel{\stackrel{\circ}{N}}{\sim}$ & ○ ㄱ & $\stackrel{\circ}{+}$ & $\stackrel{ }{\stackrel{2}{二}}$ & $\stackrel{\circ}{\Perp}$ & $\stackrel{\bullet}{\nwarrow}$ & $\underset{\infty}{+}$ & $\bar{\kappa}$ & $\underset{\sim}{\sim}$ & 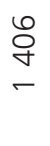 \\
\hline $\begin{array}{l}\text { West-Mediter- } \\
\text { ranean route }\end{array}$ & $\begin{array}{l}8 \\
\text { 유 } \\
6\end{array}$ & $\begin{array}{l}\stackrel{\circ}{ก} \\
6 \\
6\end{array}$ & 옹 & $\begin{array}{l}\stackrel{\circ}{\oplus} \\
\stackrel{\infty}{\infty}\end{array}$ & $\begin{array}{l}\text { ○ } \\
\text { ণ } \\
6\end{array}$ & $\begin{array}{l}8 \\
\infty \\
0\end{array}$ & $\stackrel{m}{\underset{\sim}{\sim}}$ & 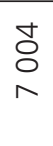 & $\begin{array}{l}\text { Я } \\
\text { の } \\
\text { の }\end{array}$ & $\underset{\stackrel{m}{\sim}}{\stackrel{m}{\sim}}$ & 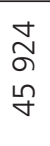 \\
\hline $\begin{array}{r}\text { Trail through } \\
\text { Apulia and } \\
\text { Calabria }\end{array}$ & & ) & $\begin{array}{l}\infty \\
\infty \\
\sim \\
\sim\end{array}$ & $\begin{array}{l}\stackrel{\mathcal{N}}{N} \\
\text { in }\end{array}$ & $\underset{\substack{N \\
N}}{\stackrel{2}{N}}$ & $\begin{array}{l}8 \\
8 \\
\text { เn }\end{array}$ & $\stackrel{\dot{\sigma}}{\check{c}}$ & 迥 & 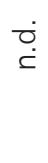 & 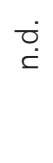 & 它 \\
\hline $\begin{array}{r}\text { Central- } \\
\text { Mediterranean } \\
\text { route }\end{array}$ & $\begin{array}{l}\text { ○ } \\
\infty \\
\circ \\
\text { m }\end{array}$ & $\begin{array}{l}8 \\
8 \\
=\end{array}$ & $\begin{array}{l}\bigcirc \\
\stackrel{1}{\circ} \\
\forall\end{array}$ & 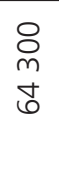 & $\begin{array}{l}8 \\
8 \\
\text { ำ } \\
-1\end{array}$ & $\begin{array}{l}\text { ○ } \\
8 \\
\circ \\
\circ\end{array}$ & \begin{tabular}{l}
\multirow{6}{0}{} \\
0 \\
0 \\
\hdashline
\end{tabular} & $\begin{array}{l}0 \\
\text { on } \\
m \\
\\
\end{array}$ & $\begin{array}{l}w \\
\stackrel{n}{m} \\
\infty \\
\infty\end{array}$ & $\begin{array}{l}\text { రీ } \\
\infty \\
\infty \\
\leftarrow\end{array}$ & $\begin{array}{l}\stackrel{\operatorname{n}}{\kappa} \\
\stackrel{\sim}{\sim}\end{array}$ \\
\hline $\begin{array}{r}\text { The route } \\
\text { from Albania } \\
\text { to Greece }\end{array}$ & \begin{tabular}{l}
$\stackrel{8}{8}$ \\
$\stackrel{+}{\sim}$ \\
\multirow{\gamma}{*}{}
\end{tabular} & $\begin{array}{l}8 \\
8 \\
\circ \\
\circ\end{array}$ & $\begin{array}{l}\bigcirc \\
\stackrel{m}{m} \\
\stackrel{n}{m}\end{array}$ & $\begin{array}{l}\stackrel{一}{\circ} \\
\text { Ln }\end{array}$ & $\begin{array}{l}\text { 오 } \\
\text { セn } \\
\text { เn }\end{array}$ & $\begin{array}{l}\stackrel{\circ}{\circ} \\
\infty \\
\infty\end{array}$ & $\underset{\infty}{\bar{\delta}}$ & $\begin{array}{l}\tilde{n} \\
\infty \\
\infty\end{array}$ & $\frac{\bar{\Sigma}}{\text { in }}$ & $\begin{array}{l}\text { o } \\
\text { m } \\
6\end{array}$ & \begin{tabular}{l}
\multirow{6}{\sigma}{} \\
$m$
\end{tabular} \\
\hline $\begin{array}{l}\text { East- Mediter- } \\
\text { ranean route }\end{array}$ & $\begin{array}{l}8 \\
m \\
\text { ก̃ }\end{array}$ & $\begin{array}{l}\bigcirc \\
8 \\
\circ \\
\circ\end{array}$ & 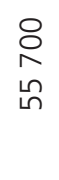 & $\begin{array}{l}8 \\
8 \\
\text { เก }\end{array}$ & 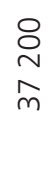 & 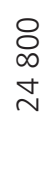 & $\begin{array}{l}\stackrel{+}{m} \\
\infty \\
\circ \\
\text { ம }\end{array}$ & $\begin{array}{l}\infty \\
\infty \\
m \\
\infty \\
\infty \\
\infty\end{array}$ & $\begin{array}{l}\underset{N}{N} \\
\text { } \\
\sim\end{array}$ & $\begin{array}{l}\stackrel{\text { O }}{\mathrm{m}} \\
\stackrel{\sim}{*}\end{array}$ & $\frac{\stackrel{n}{\sim}}{\stackrel{\sim}{\forall}}$ \\
\hline $\begin{array}{r}\text { West- Balkan } \\
\text { route }\end{array}$ & 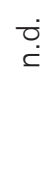 & $\begin{array}{l}\text { ㅇ } \\
\text { m } \\
\text { m }\end{array}$ & $\stackrel{\circ}{\stackrel{m}{v}}$ & $\begin{array}{l}\circ \\
\stackrel{1}{0} \\
\ddots\end{array}$ & $\begin{array}{l}\stackrel{\circ}{\mathrm{m}} \\
0\end{array}$ & $\begin{array}{l}\text { 음 } \\
\text { ڤ̆ } \\
\text { ㅁ }\end{array}$ & 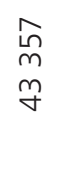 & 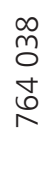 & 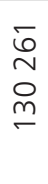 & $\frac{\infty}{\check{\Sigma}}$ & 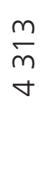 \\
\hline $\begin{array}{r}\text { migration } \\
\text { route/number } \\
\text { of crossings }\end{array}$ & $\begin{array}{l}\infty \\
\stackrel{2}{~}\end{array}$ & ஓे & $\stackrel{\circ}{\circ}$ & $\underset{\sigma}{\bar{\sigma}}$ & $\stackrel{\sim}{\sim}$ & $\stackrel{m}{\stackrel{m}{\sigma}}$ & $\underset{ণ}{\stackrel{\Xi}{ত}}$ & $\stackrel{\llcorner}{\circ}$ & 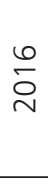 & 홍 & 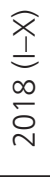 \\
\hline
\end{tabular}


According to Frontex, this means that 'the actual burden on external borders remains high'21. The above numbers illustrate the scale of the problem. Migration pressures at the EU's external borders, and later on the territory of the Member States, led to a stalemate which, based on recent media reports on the conflict around Aquarius, it seems will not be easy to resolve ${ }^{22}$.

The mass influx of immigrants (including refugees) to the EU has forced all interested parties, i.e. the EU institutions and the Member States, to:

- deal with their rapid and increasing influx;

- take appropriate actions and decisions regarding their adoption and deployment;

- stop subsequent migration waves.

In crisis situations it is usually harder to find a common language. In this case, significant differences in positions caused divisions within the EU. The 'bone of contention' was both the approach to the problem of refugees within the EU and the manner of its solution. The reasons for the lack of unity are seen in the different tradition of admitting immigrants (including refugees) due to the different historical and cultural factors. In the context of the emergence of thousands of immigrants (including refugees) on the northern shores of the Mediterranean, EU Member States can be divided into four groups, namely: 'first front' (Greece, Italy, Spain), transit (Hungary, Croatia, Austria), target (mainly from Western and Northern Europe), and those sceptical about accepting refugees (mainly from Central and Eastern Europe). These divisions became more acute when EU institutions decided to initiate (and to some extent impose) actions on several levels to quickly, efficiently and effectively curb the wave of mass influx of immigrants from Middle East, North Africa and subSaharan Africa (see Table 2).

Although undertaking joint actions aimed at stopping the uncontrolled inflow of immigrants seems to be most appropriate, subsequent Member States independently decided to take action to protect their own borders and citizens ${ }^{23}$. As J. Szymańska

21 The author, due to the limited volume of the article, refers only to the statistics of the independent EU agency - Frontex, which in 2016 was transformed into the European Border and Coast Guard Agency. Its tasks included not only migration control, but also border management and greater responsibility for combating cross-border crime, as well as actions to search and rescue people in situations related to the protection of sea borders. More: J. Kopeć, K. Korzeniowska (2018), Spada liczba osób nielegalnie przekraczających granice Unii. Ale za jaką cenę?, „Wyborcza”, 28 February, www.wyborcza.pl [Accessed: 15.08.2018].

22 'The drifting Aquarius of the SOS Mediterranee with 629 people on board is also a symbol of the dysfunctional asylum system in Europe'. More: Amnesty International (2018), Reforma systemu azylowego UE: szansa na realne zmiany dla uchodźców, https://amnesty.org.pl/reforma-systemu-azylowego-ueszansa-na-realne-zmiany-dla-uchodzcow/ [Accessed: 15.08.2018].

${ }^{23}$ For the first time since the fall of the Berlin Wall, fences were built along borders and once again border controls were carried out. In April 2011, in Ventimiglia, migrants from Tunisia trying to make their way from Italy to France were detained at the border and sent back to Italy. This reaction became a source of conflict and led to a crisis in the Schengen area. 


\section{SM̂PP}

Table 2

Plans for solving the problems of refugees in the European Union

\begin{tabular}{|c|c|c|c|c|}
\hline $\begin{array}{l}\text { Strengthening } \\
\text { the control } \\
\text { of the EU's } \\
\text { external } \\
\text { borders }\end{array}$ & $\begin{array}{c}\text { A fair } \\
\text { distribution } \\
\text { of refugees }\end{array}$ & $\begin{array}{l}\text { Improving } \\
\text { the asylum } \\
\text { procedure }\end{array}$ & $\begin{array}{l}\text { Improving } \\
\text { the living } \\
\text { conditions of } \\
\text { refugees }\end{array}$ & $\begin{array}{l}\text { Stabilization } \\
\text { of the } \\
\text { situation in } \\
\text { the countries } \\
\text { of origin }\end{array}$ \\
\hline $\begin{array}{l}\text { - EU external } \\
\text { borders must } \\
\text { be controlled } \\
\text { - the above sit- } \\
\text { uation opens } \\
\text { the way to } \\
\text { obtaining } \\
\text { asylum and } \\
\text { staying in the } \\
\text { EU }\end{array}$ & $\begin{array}{l}\text { - developing } \\
\text { an appropri- } \\
\text { ate system } \\
\text { for allocat- } \\
\text { ing refugee } \\
\text { quotas }\end{array}$ & $\begin{array}{l}\text { - Member } \\
\text { States should } \\
\text { standardize } \\
\text { and intro- } \\
\text { duce clear } \\
\text { asylum pro- } \\
\text { cedures } \\
\text { - increasing } \\
\text { integration } \\
\text { efforts to- } \\
\text { wards asylum } \\
\text { seekers }\end{array}$ & $\begin{array}{l}\text { - it is necessary } \\
\text { to increase } \\
\text { efforts at } \\
\text { the EU level } \\
\text { to improve } \\
\text { the living } \\
\text { conditions of } \\
\text { refugees in } \\
\text { neighboring } \\
\text { countries to } \\
\text { the countries } \\
\text { of origin }\end{array}$ & $\begin{array}{l}\text { - greater ef- } \\
\text { forts for } \\
\text { achieving } \\
\text { peace } \\
\text { - improving } \\
\text { the situation } \\
\text { in Syria and } \\
\text { neighboring } \\
\text { countries }\end{array}$ \\
\hline
\end{tabular}

Source: K. A. Wojtaszczyk (2017), Kryzys uchodźczy jako wyzwanie dla przyszłości projektu integracyjnego w Europie, in: Wojtaszczyk, K. A., Szymańska, J. (eds.), Uchodźcy w Europie. Uwarunkowania. Istota. Następstwa, Warszawa: Oficyna Wydawnicza ASPRA-JR, p. 198.

points out: 'The migration crisis hits the very core of freedom, security and justice areas integrated in the Treaty of Lisbon, and so the twin priorities of freedom and security'24. Various reactions of EU institutions and individual Member States to the increased wave of migrants (including refugees) forced on the one hand - the strengthening of the integrity of the Schengen area as a whole, and on the other strengthening the integrity of the EU's external borders. Reforms were unavoidable, because building walls (figuratively and literally) questioned the notion of the 'Europe without borders' 25 . project that had been in existence for over 25 years ${ }^{26}$. The discussion concerning reforming the management of the Schengen area revealed a number of contradictions between the parties involved - in particular, the dispute concerned various visions of the new Schengen system. One was promoted by the EU

24 J. Szymańska (2016), Międzyrządowość vs. ponadnarodowość w polityce migracyjnej i obszarze spraw wewnętrznych Unii Europejskiej, in: Grosse, T. G. (ed.), Polityki europejskie w dobie kryzysu, Warszawa: Wydawnictwo Naukowe SCHOLAR, pp. 253-274.

25 J. Szymańska (2018b), Kontrole na granicach wewnętrznych strefy Schengen: wyjątki stają się regułą, „Biuletyn PISM" 17(1590), https://www.pism.pl/publikacje/biuletyn/nr-17-1590 [Accessed: 10.08.2018].

26 More: W. Böhm (2011), Ein Rückbau der EU in die nationale Beschaulichkeit, 'Die Presse', 12 May, www.diepresse.com [Accessed: 15.08.2018]. 
institutions, while others were preferred by the Member States ${ }^{27}$. While the Commission suggested a pan-European approach, by ensuring the integrity of the Schengen area as a whole and restricting the freedom of states' decisions concerning temporary reintroduction of border controls, many Member States preferred a completely different approach ${ }^{28}$. Hugo Brady distinguished four groups involved in this dispute:

1. nervous policemen, i.e. countries of North-Western Europe (with France and Germany at the forefront), according to whom Schengen and other border regulations turned out to be insufficient to ensure internal security,

2. dissatisfied border guards, i.e. southern European countries (with Greece and Italy in the lead) whose external borders and asylum systems have come under particular pressure and have not received sufficient support from other European countries,

3. idealistic enthusiasts of the free movement of persons, i.e. new members of Schengen (especially countries of Central and Eastern Europe), for whom freedom of travel is extremely valuable, if only due to historical limitations,

4. libertarian attorneys, i.e. the EU institutions, in particular the Commission, the European Parliament, the Court of Justice of the EU, for whom the most important task is to defend European 'openness'29.

The divergence of the interests of the parties involved in this dispute made it difficult to find a compromise. The ongoing discussion on the reform package of the Schengen system has been extremely turbulent since the outset, but eventually, after almost two years, on 12.6.2013, a compromise was reached, even if it was a bitter one ${ }^{30}$.

The heated dispute over Schengen was, however, only the 'tip of the iceberg'. In order to avoid a situation in which the basic principles of cooperation under the AFSJ

27 In the Polish daily Rzeczpospolita, the publicist Marek Magierowski writes about whether the planned deviations from the rule of free movement of people will not make this 'noble idea cease to be an EU dogma'. Similarly, in the Estonian newspaper Postimees, the commentator Livi A. Masso regrets that after years of effort put into promoting a free and safe Europe, we are increasingly striving towards the opposite. More: R. Burki (2011), Schengen: Back to the nation oasis, 'Die Presse', 13 May, www.diepresse.com [Accessed: 15.08.2018].

28 France and Italy, with the support of German diplomacy, lobbied for the reintroduction of controls at internal borders. Poland, which then held the presidency of the EU Council, indicated that such a move would be nothing but a denial of the idea of 'Europe without borders' and postulated actions to improve border management in the Schengen area and establishment of new instruments of immigration and asylum policy, allowing the legalization of immigration and creation of an 'effective and sustainable return and readmission policy'. In light of these disputes, the European Commission allowed the unilateral reintroduction of border controls by a Member State in the event of 'extraordinary circumstances'. However, at the same time it was emphasized that such controls could be restored after using other available immigration management measures, as well as being territorially and temporarily limited.

29 More: H. Brady (2012), Saving Schengen. How to protect passport-free travel in Europe, https:// www.opensocietyfoundations.org/sites/default/files/2012-01_Saving\%2520Schengen.pdf [Accesed: 15.10.2018].

30 J. Szymańska (2016), Międzyrządowość vs. ponadnarodowość ..., p. 265. 


\section{SM̂PP}

would be completely undermined, the EU institutions increasingly began to promote the idea of consolidation and coordinated action. Unfortunately, the uncertain times and rapidly changing circumstances in the world have only forced changes in EU policy, leading to non-emergency solutions (because these did not bring the expected results), but comprehensive ones that will work in all conditions. Therefore, the first major anti-crisis initiative that cemented all levels of the solution to the problems of refugees in the EU (see Table 2) was the Agenda for Migration of 2015 $25^{31}$. The intention of its authors was to stimulate reform in the area of cooperation in the field of migration and asylum through:

- management of the Schengen area as part of the European migration program and implementation packages attached to it;

- a comprehensive approach to the problem of migration and refugees in crisis conditions based on the concept of relocation and resettlement ${ }^{32}$,

- reform of the Common European Asylum System;

- improvement of the system of protection of EU external borders and mechanisms for combating smuggling and trafficking in human beings within the framework of intra-EU cooperation and cooperation with third countries (including: rescue and patrol operations in the Mediterranean Sea coordinated by Frontex, military operations in the field of common policy security and defense against human smugglers, creating points for quick identification and registration of immigrants in Italy and Greece under the so-called 'Hotspot' approach;

- management of the EU's external borders and increasing internal security within the so-called the smart border package, i.e. a new instrument for border management ${ }^{33}$ : a European travel information system and travel authorizations and an entry / exit system ${ }^{34}$;

- establishing cooperation with third countries under the so-called a global approach to migration and mobility issues from $2011^{35}$.

${ }^{31}$ EC (2015b), A European Agenda on Migration, Brussels 13.5.2015, COM(2015) 240 final.

32 Relocation means the transfer of a person who has applied for international protection from a Member State examining its application to another Member State. Resettlement involves the transfer of a 'non-EU' refugee evidently requiring international protection from a non-EU country to an EU Member State. More: K. Cymbranowicz (2017), Europa (bez)granic - w poszukiwaniu rozwiązania kryzysu migracyjnego w Unii Europejskiej, in: Tendera-Właszczuk, H., Bąba, W., Zajączkowska, M. (eds.), Nowe perspektywy integracji europejskiej w obliczu wyzwań i zagrożeń, Warszawa: Difin, pp. 48-79.

${ }_{33}$ The basis for their creation was the Smart Borders Package proposed by the European Commission in 2013.

${ }^{34}$ This activity is part of a long-term plan to ensure an effective response to terrorism and security threats in the EU for the years 2015-2020 within the framework adopted on 28.4.2015 The European Agenda on Security (EC (2015c), The European Agenda on Security, Brussels 28.4.2015, COM(2015) 185 final), and statement Back to Schengen - a Roadmap from 4.3.2016 (EC (2016d), Back to Schengen a Roadmap, Brussels 4.3.2016, $\operatorname{COM(2016)~} 120$ final).

${ }^{35}$ EC (2011), The Global Approach to Migration and Mobility, Brussels 18.11.2011, COM(2011) 743 final. 
Although the adopted assumptions and the chosen directions seemed to be right, it quickly transpired that European unity and solidarity are values which are difficult to retain in times of crisis. EU member states divided into at least two 'camps' with extremely different views: one of them was the 'open door policy' scenario promoted by the German Chancellor - Angela Merkel (Wilkommenspolitik), while others opted for a 'closed door policy' called 'Fortress Europe' as promoted by the Hungarian Prime Minister, Victor Orban ${ }^{36}$.

The most controversial issue was the initiative of a comprehensive approach to the problem of migration in the context of the crisis based on a system of relocation and resettlement ${ }^{37}$. The first proposal regarding the distribution of people who were to be relocated or resettled was reported by the European Commission on 13.5.2015. Two weeks later, as proposed by the European Commission, EU Member States were obliged by the Council of the EU to accept 40,000 people under the relocation mechanism from Greece and Italy and 20,000 as part of the resettlement mechanism. However, not all of them declared a readiness to implement the plan. Opposition to the 'open door policy' was displayed by the authorities of Hungary, the Czech Republic, Slovakia and Poland, who claimed that these solutions should be based on the principle of flexible solidarity and voluntariness. This 'insubordination' was met with a sharp reaction from Austria, France and Germany, who did not spare criticism of their 'morally repugnant' ${ }^{38}$ attitude:

- Johanna Mikl-Leitner recognized that the pressure on Hungary, the Czech Republic, Slovakia and Poland must include all available means, including 'suspension or even withdrawal of subsidies under European funds'39;

- French President Francois Hollande pointed out that: 'The European Union is a community of values. Those who do not share these values question their presence in the European Union. ${ }^{40 ;}$

- German Chancellor - Angela Merkel said that this 'collective problem needs collective solutions';

${ }^{36}$ Poland found itself in a group of countries unwilling to accept immigrants, forming a coalition with Hungary, the Czech Republic and Slovakia.

37 Support for the relocation system was expressed by 18 EU Member States. Opposition was reported by the Visegrad Group countries (except Poland) and the Romanian authorities. Finland abstained from voting. Three countries have been excluded from the relocation system: Great Britain, Ireland and Denmark (based on Article 1 and 2 of Protocol 22 attached to TFEU). Also, a temporary suspension of the obligation to participate in the relocation system for a period of 12 months has been applied to Sweden and Austria.

38 More: Eastern Europe's Short Memory (2015), 'The New York Times', 15 September, www.nytimes.com [Accessed: 15.08.2018].

39 M. Feher, A. Thomas (2015), Austria Toughens Controls Amid European Migrant Crisis, 'The Wall Street Journal', 31 August, www.wsj.com [Accessed: 15.08.2018].

40 V. Pop, L. Norman, S. Fidler (2015), EU Leaders Agree to Modest Measures for Handling Growing Migrant Crisis, 'The Wall Street Journal', 23 September, www.wsj.com [Accessed: 15.08.2018]. 


\section{SM̂PP}

and called for joint responsibility in the face of the migration crisis, which is a challenge not only for Germany, but for all of Europe ${ }^{41}$.

The polarization of the positions of the 'European family' countries deepened after 31.8.2015. Angela Merkel uttered the memorable words - 'Wir haben so vieles geschafft - wir schaffen das' ('We have managed so many things - we will also manage this situation'), independently deciding to suspend the Dublin II Regulation against Syrian migrants ${ }^{42}$. It is impossible to deny the German Chancellor's good intentions ('The heart has its reasons, which the mind does not know' as Blaise Pascal wrote), what's more, in this case, these were not just empty words - on the night of 4-5.9, German authorities allowed thousands of refugees who were staying in Hungary to enter Germany. The German weekly Die Zeit compared this decision to the events of November 1989 describing it as the 'second fall of the Berlin Wall' or 'decision changing the continent'. However, not everyone shared this enthusiasm - an unprecedented declaration in the spirit of European humanism combined with such a strong message was both praised and criticized $^{43}$. The answer to the question of whether the Germans did not overestimate their capabilities came relatively quickly, because already on 14.9.2015, in a rather tense atmosphere, the Council of the EU adopted the arrangements for the distribution of 40,000 and on 22.9 - another 120,000 asylum seekers in Greece, Italy and other EU Member States directly affected by the crisis. If the solutions adopted pursuant to the decision of September 14th did not raise any doubts (because they referred to the arrangements made by consensus on July $20^{\text {th }}$, based on resolution of the Representatives of the Governments of the Member States meeting within the Council on relocating from Greece and Italy 40,000 persons in clear need of international protection), the dissatisfaction was triggered by the decision of September 22nd (because it was decided by a qualified majority - influenced by France and Germany, unexpectedly supported by Poland ${ }^{44}$ and Latvia - so far reluctant to subscribe to the obligatory quota system ${ }^{45}$ ).

${ }^{41} \mathrm{~N}$. Nougayrede (2015), Angela Merkel is right: the migration crisis will define this decade, 'The Guardian', 21 August, www.theguardian.com [Accessed: 15.08.2018].

42 More: J. Delcker (2016), The phrase that haunts Angela Merkel. A year on and the German leader hasn't recovered from 'we can do it', 'Politico', 19 August, https://www.politico.eu/ [Accessed: 15.08.2018].

${ }^{43}$ More: G. Diez (2015), Ja, wir schaffen das, 'Der Spiegel', 25 October, www.spiegel.de [Accessed: 15.08.2018]; N. Abé, M. Amann, H. Gude, P. Müller, R. Neukirch, R. Pfister, B. Schmid, Ch. Schult, H. Stark, W. Wiedmann-Schmidt (2015), Herzdame, 'Der Spiegel', 19 September, www.spiegel.de [Accessed: 15.08 .2018$]$.

44 Initially, Poland was the only Visegrad country to agree in September 2015 to the solution proposed by the EU, i.e. the division of 120000 refugees. At that time, criticism fell on the government of Ewa Kopacz, and the media announced the end of Visegrad. When, after the election in October 2015 the government changed, the new government headed by Beata Szydło changed the previous arrangements and joined the position expressed by the partners from the Visegrad Group.

${ }^{45}$ In addition, the contentious issue of the coalition reluctant were the provisions regarding 'financial penalties' resulting from non-compliance - if for a justified reason the Member State does not accept immigrants under relocation, then it will be required to pay an amount of $0.002 \%$ of GDP to the EU budget (exceptions were allowed). 
Hungary, Slovakia, the Czech Republic and Romania treated Polish consent to the agreement as a betrayal, and the decision taken as a dictate on the part of Germany. The Hungarian Prime Minister, Victor Orban, recognized the system of relocation and resettlement as a German invention and accused Angela Merkel of 'moral imperialism' and an attempt to impose on the other member states her own vision of an open $\mathrm{EU}^{46}$. Despite the objections raised, both mechanisms begun to function, although it must be admitted that with different results. Particularly prophetic were the words of the Minister of Internal Affairs of the Czech Republic, Milan Chovanca, which were published on Twitter: 'a common sense has lost and soon we will learn that the emperor is naked'47. Despite the initial declarations of the absolute necessity of accepting refugees from the North African and Middle East region, when it came to turning words into deeds, this solution transpired to have fewer supporters than opponents ${ }^{48}$. More and more people agreed with the Visegrad Group countries, claiming that the creation of a relocation and resettlement system was no way to solve the problem - it is a utopia 'because it is only a treatment of consequences, not causes, paradoxically leading to the intensification of migratory pressure ${ }^{\prime 49}$. With time, one could discern melting support for this solution and a gradual retreat from the policy of openness. More and more frequent reports of tragic accidents involving immigrants (including refugees) at sea and on land, as well as information about the continuing pushing of the 'gates of Europe' (not only the southern EU external borders, but also the borders of the so-called transit countries) were disturbing. Another wave of criticism fell on countries promoting welcome culture in November 2015, when the whole world heard about terrorist attacks in the French capital. The tragic events in Paris changed the optics for a liberal approach towards foreigners coming to the EU. Protection of the territories of EU Member States and the Schengen area against 'foreign flooding' became a priority. There was a slow retreat from the 'open door policy' for not so much 'demolishing bridges and building walls, fences or entanglements' in the scenario of the 'Europa Fortress', but to shifting the emphasis to the implementation of another element of the Agenda ..., i.e. management of the EU's external land and sea borders in cooperation with third countries. The Visegrad Group states have repeatedly emphasized how important it is to:

46 D. Nolan (2015), Refugee crisis: EU divided as Hungary attacks migrant quota as 'unrealisable and nonsense', 'The Telegraph', 23 September, www.telegraph.co.uk [Accessed: 15.08.2018].

47 Czesi rozczarowani postawą Polski. Prasa: Polska zawiodła. Grupa Wyszechradzka się rozpadła (2015), „wPolityce”, 23 September, www.wpolityce.pl [Accessed: 15.08.2018].

${ }_{48}$ More: T. Bielecki (2015), Imigracja dzieli Unię - 'nowa' Europa nie chce obowiązkowych kwot uchodźców, "Wyborcza”, 16 June, www.wyborcza.pl [Accessed: 15.08.2018]; Przyjmowanie imigrantów dzieli Europę. Jest oficjalny sprzeciw (2015), „Wprost", 10 September, www.wprost.pl [Accessed: 15.08.2018]; A. Słojewska (2018), Imigranci znów dzielą Unię, „Rzeczpospolita”, 25 June, www.rzeczpospolita.pl [Accessed: 15.08.2018].).

${ }^{49}$ A. Potyrała (2016), Środkowoeuropejska koalicja niechętnych wobec kryzysu migracyjnego 2015- 


\section{SM̂PP}

- create protection of the EU's external borders, so that the EU would take effective measures limiting the inflow of immigrants;

- counteract the real causes of migration, through efforts to end the conflict in Syria, stabilize the situation in Iraq and in North African countries;

- cooperate with third countries (transit ones), including Turkey.

This perspective began to be shared by others, including countries outside the EU (e.g. Macedonia) or in the Schengen area (e.g. Bulgaria).

The issue of accepting and deploying immigrants, although still important, was moved to the second plane - earlier divergences on this issue, which divided the EU so much, gradually began to become blurred ${ }^{50}$. For example, the Prime Minister of France - Manuel Valls, said bluntly: 'It's not France who said come!', Thus suggesting that the situation arose from the actions of Germany and their policies ${ }^{51}$. It remains an open question of whether this is a fair assessment. However, when the issue of the security of the state and its citizens on the one hand is at stake, and humanitarian issues with regard to 'strangers' on the other, the result seems to be settled.

Due to the continuing crisis and difficulties with the implementation of the relocation and resettlement plan, the European Commission returned to the issue contained in the Agenda... of 2015, regarding sustainable systemic asylum solutions, including the establishment of a mechanism for the division of refugees which would be automatically activated in crisis situations ${ }^{52}$. Nobody challenged the need to reform the Common European Asylum System - CEAS ${ }^{53}$, but the controversies were raised by the proposal to reform the Dublin system, i.e. Dublin + project. It is a mechanism that has been discussed many times on the EU level and concerns the automatic relocation of persons applying for protection in the $\mathrm{EU}$ in the situation of increased migratory pressure. According to the project:

- verification of overloading of asylum systems would be based on indicators taking into account the size of countries and the level of their well-being;

- a 'surplus' of asylum applications in one Member State would result in the transfer of further applicants to other countries;

- temporary exclusion of the state from the obligation to accept asylum seekers would require the payment of a 'solidarity tax' (EUR 250 000) to a Member State that would take over responsibility for examining the application.

50 J. Kapiszewski, M. Cedro (2018), Twierdza Europa. Polityka migracyjna dzieli Stary Kontynent, choć liczba imigrantów spada, „Dziennik Gazeta Prawna”, 6 July, www.gazetaprawna.pl [Accessed: 15.08.2018].

51 Valls ostrzega przed rosnącą liczbą uchodźców (2015), https://euroislam.pl/valls-ostrzega-przed-rosnaca-liczba-uchodzcow/ [Accessed: 15.08.2018].

52 EC (2016b), Proposal for a Regulation of the European Parliament and of the Council establishing the criteria and mechanisms for determining the Member State responsible for examining an application for international protection lodged in one of the Member States by a third-country national or a stateless person (recast), Brussels 4.5.2016, COM(2016) 270 final.

53 It was considered that it does not work properly, because asylum seekers are not treated equally everywhere, and the recognition rates of individual countries vary. 
The Dublin + project was not well received by all member states - it was criticized above all by the Visegrad Group countries (the Hungarian representative called it 'blackmail', Poland - 'April Fool's joke', and Slovakia claimed that it 'does not fit into reality'54. During the Polish Presidency, on 21.11.2016, the Visegrad Group adopted a declaration regarding the creation of a Migration Crisis Mechanism. The result was a counter-proposal to the obligatory quota system of the European Commission, i.e. 'effective' solidarity (originally known as 'flexible' solidarity). Pointing to the need to regain control over current migration flows, this concept was based on the principle that each Member State would have to decide for itself how specifically it would contribute to the fight against the crisis. In fact, this proposal concentrates on preserving the solutions of the Dublin III regulation of 2013, combined with solidarity activities with first-line countries in a crisis situation. According to this project, Member States would be free to decide what form their assistance would take: apart from relocations from the most heavily loaded countries, these could be financial contributions, increased involvement in the work of EU agencies, taking responsibility for organizing the return of illegal immigrants or jointly carrying out asylum procedures ${ }^{55}$.

Observing the current course of the debate on the CEAS reform, it can be concluded that working out a compromise between two such different concepts will not be easy. Despite the fact that this subject was repeatedly undertaken at subsequent European Council summits, it was only during the December summit (14-15.12.2017) that a decision was made that by the end of June 2018, an agreement concerning the CEAS reform shall be made. However, during the summit of the European Council on 28-29.6.2018, no final decisions were made. The Council is examining seven legislative proposals made by the European Commission to improve EU asylum rules. Although progress was made, the question of solidarity and responsibility under the two remaining questions, the Dublin Regulation and the Regulation on Asylum Procedures, remains an outstanding issue.

The next step taken by the EU to overcome the crisis was to improve the system of the protection of external borders and to develop mechanisms to fight smuggling and trafficking humans. The proposals made in this area have been widely supported by all Member States. Examples of such wide-ranging cooperation in the EU are:

- rescue and patrol operations in the Mediterranean Sea coordinated by the Frontex agency56: 'Poseidon' off the coast of Greece (from 2006), 'Triton' off the coast of Italy (from 2014) - replaced in 2018 by operation 'Themis' cov-

54 'Szantaż', 'primaaprilisowy żart' i 'atak na suwerenność'. Grupa V4 ostro o planie KE (2016), http:// www.tvn24.pl/wiadomosci-ze-swiata,2/polska-i-wegryostro-krytykuja-propozycje-nowej-polityki-azylowejue,640973.html [Accessed: 4.08.2018].

55 In an emergency situation it would be possible to adopt measures from art. 78 par. 3 TFEU, with the proviso that they would be voluntary and not mandatory.

56 Doubts are have been aroused by the fact that Frontex is primarily responsible for controlling 


\section{SM̂PP}

ering also the prevention of possible terrorist attacks by the so-called Islamic State in European countries, and 'Hera', 'Indalo' and 'Minerva' off the coast of Spain (from 2017),

- military operations in the field of common security and defence policy against smugglers in the southern Mediterranean region EU NAVFOR MED 'Sophia' (from 2015) in combination with the EU action plan to combat migrant smuggling 2015-202057,

- creation of points for the quick identification and registration of immigrants in Italy and Greece within the so-called the Hotspot approach, which consists of joining together the forces of several EU agencies - EASO, Frontex, Europol and Eurojust for the effective management of migratory flows in emergency situations (see map 1).

Map 1

Location of 'hotspots' in Italy and Greece and the capacity of these centers to receive migrants

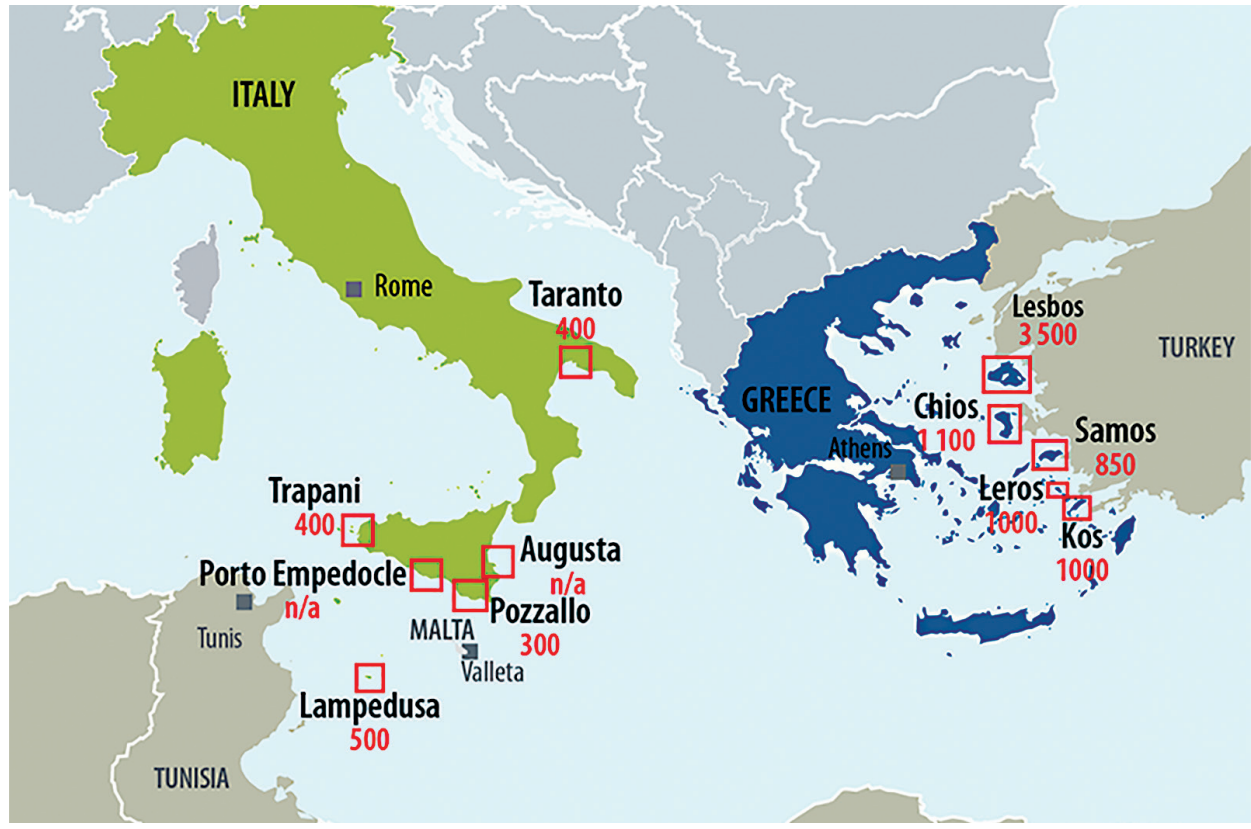

Note: In the case of Italy, six originally proposed hotspot locations were included, two of which (Augusta and Porto Empedocle) were eventually not used.

Source: European Court of Auditors (2017), EU response to the refugee crisis: the 'hotspot' approach, http:// publications.europa.eu/webpub/eca/special-reports/refugee-crisis-hotspots-06-2017/en/ [Accessed: 4.08.2018].

hazards, and not engaging in search and rescue activities. Nonetheless, previous search and rescue missions were deemed to only encouraged migrants to risk the crossing. M. Szczepanik (2015), Mare Nostrum, „Biuletyn Migracyjny” 51, pp. 2-3.

57 EC (2015a), EU Action Plan against migrant smuggling (2015-2020), Brussels 27.5.2015, $\operatorname{COM}(2015) 285$ final. 
In addition, issues related to strengthening the security of the EU's external borders were addressed in the Third package of implementing measures to the European Agenda on Migration of 15.12.2015. Not all of the proposals contained in it have been welcomed by the Member States. This was the draft regulation establishing the European Border and Coast Guard, which was to be supplemented by the revision of the Schengen Borders Code. Opposition to this project was related to the granting of broader competences in the management of external borders than had been previously granted to the Frontex agency - the controversy centred around the entry that detailed how, in a situation threatening the functioning of the Schengen area, the agency will be able to intervene, even if the Member State does not express its permission. As in 2011, this time it was also a priority for the Member States to preserve their sovereignty in regard to the protection of their own borders. In the end, the profound changes in competences of the agency to be created were withdrawn and on 14.9.2016 the regulation creating the European Border and Coast Guard entered into force. Less than a month later - on 6.10, at the border crossing of Captain Andreevo on the external border of Bulgaria with Turkey, the new agency began its activities ${ }^{58}$. The proposed changes regarding the Schengen Borders Code found their final form on 15.3.201759. The new rules on mandatory and systematic checks of persons crossing the EU external borders during entry and exit responded to the growing terrorist threat in Europe.

More effective management of the EU's external borders and increasing internal security is also possible thanks to the so-called the smart borders package ${ }^{60}$. Both old and new information systems designed for this purpose are to meet the requirements of the 21 st century, especially the phenomena observed during the culmination of the crisis in 2015. The series of legislative proposals presented by the European Commission aims to modernize and optimize the EU's information infrastructure. Considering the political priority of combating the movement of unidentified migrants within the EU, the Commission presented legislative proposals for the modernization

58 Regulation (EU) 2016/1624 of the European Parliament and of the Council of 14 September 2016 on the European Border and Coast Guard and amending Regulation (EU) 2016/399 of the European Parliament and of the Council and repealing Regulation (EC) No 863/2007 of the European Parliament and of the Council, Council Regulation (EC) No 2007/2004 and Council Decision 2005/267/EC, Official Journal of the EU L 251/1, 16.9.2016.

59 Regulation (EU) 2017/458 of the European Parliament and of the Council of 15 March 2017 amending Regulation (EU) 2016/399 as regards the reinforcement of checks against relevant databases at external borders, Official Journal of the EU L 74/1, 18.3.2017.

${ }^{60} \mathrm{It}$ is worth noting that this activity is part of a long-term plan to ensure an effective response to terrorism and security threats in the EU for the years 2015-2020 as part of the adopted on 28.4.2015 The European Agenda on Security, and statement Back to Schengen - a Roadmap from 4.3.2016. See: EC (2015c), The European Agenda on Security, Brussels 28.4.2015, COM(2015) 185 final; EC (2016d), Back to Schengen - a Roadmap, Brussels 4.3.2016, COM(2016) 120 final; European Commission - Press release (2013), Smart borders: enhancing mobility and security, http://europa.eu/rapid/press-release_IP- 


\section{SM̂PP}

of existing information systems: Eurodac (May 2016), Schengen Information System II (December 2016) and Visa Information System (May 2018) and accelerated the work on the creation of a new information infrastructure under the EU's AFSJ61: European Travel Information and Authorization System (ETIAS), Entry-Exit System (EES) and European Criminal Records Information System on Third-Country Nationals and Stateless Persons (ECRIS-TCN) (see Table 3).

The development of the aforementioned information systems has been accelerated as a result of the migration and refugee crisis. As experts point out, it raises both opportunities and risks for the security and fundamental rights of EU citizens and thirdcountry nationals, because in order to strengthen the control of migration processes by services responsible for security and border surveillance, it will be possible to:

- identify people, which can contribute to accelerating the procedures for granting asylum,

- enforce decisions ordering return to persons who are not entitled to protection on the territory of the EU,

- detect crimes, including identity theft and human trafficking ${ }^{62}$.

Table 3

New EU information systems - ETIAS, EES, ECRIS-TCN

\begin{tabular}{|l|l|l|l|}
\hline System name & \multicolumn{1}{|c|}{ ETIAS } & \multicolumn{1}{c|}{ EES } & \multicolumn{1}{c|}{ ECRIS-TCN } \\
\hline Characteristics & $\begin{array}{l}\text { the system will ap- } \\
\text { ply to third-country } \\
\text { nationals who are } \\
\text { exempt from the } \\
\text { visa requirement, as } \\
\text { well as to persons } \\
\text { exempt from the } \\
\text { requirement to have } \\
\text { an airport transit } \\
\text { visa }\end{array}$ & $\begin{array}{l}\text { ter data on entry, exit } \\
\text { and non-admission } \\
\text { of third-country na- } \\
\text { tionals who cross the } \\
\text { external borders of } \\
\text { the Schengen area }\end{array}$ & $\begin{array}{l}\text { to provide Member States } \\
\text { with information on con- } \\
\text { victions issued against } \\
\text { third-country nationals } \\
\text { and stateless persons for } \\
\text { the purpose of comple- } \\
\text { menting and supporting } \\
\text { the European criminal }\end{array}$ \\
& & & $\begin{array}{l}\text { records information sys- } \\
\text { tem (the new system will } \\
\text { be complemented by the } \\
\text { ECRIS system operating } \\
\text { since 2012 to exchange } \\
\text { data on convictions issued } \\
\text { towards EU citizens) }\end{array}$ \\
& &
\end{tabular}

${ }^{61}$ The basis for their creation became the so-called Smart Borders Package proposed by the European Commission in 2013.

62 J. Szymańska (2018a), Scentralizowane systemy informacyjne w zarządzaniu procesami migracyjnymi w UE, „Biuletyn PISM" 122(1695), http://www.pism. pl/publikacje/biuletyn/nr-122-1695 [Accessed: 10.08.2018]. 
Table 3 cont.

\begin{tabular}{|c|c|c|c|}
\hline Work progress & $\begin{array}{l}\text { - On 16.11.2016, } \\
\text { the European } \\
\text { Commission pre- } \\
\text { sented a draft } \\
\text { application on } \\
\text { ETIAS } \\
\text { - The European } \\
\text { Commission, } \\
\text { the European } \\
\text { Parliament and } \\
\text { the Council have } \\
\text { agreed positions } \\
\text { - Formal adoption } \\
\text { planned for au- } \\
\text { tumn } 2018\end{array}$ & $\begin{array}{l}\text { - On 6.4.2016, } \\
\text { the European } \\
\text { Commission present- } \\
\text { ed the draft applica- } \\
\text { tion for the EES } \\
\text { - The European } \\
\text { Commission, the } \\
\text { European Parliament } \\
\text { and the Council have } \\
\text { agreed positions } \\
\text { - On } 20.11 .2017 \text {, the } \\
\text { Council adopted an } \\
\text { entry/exit system } \\
\text { regulation and a reg- } \\
\text { ulation amending the } \\
\text { Schengen Borders } \\
\text { Code in view of this } \\
\text { system } \\
\text { - On } 30.11 .2017 \text {, } \\
\text { the Council and the } \\
\text { European Parliament } \\
\text { signed the regulation } \\
\text { - The eu-LISA Agency } \\
\text { together with the } \\
\text { Member States will } \\
\text { start the construction } \\
\text { of a new system - it } \\
\text { should be ready by } \\
\text { 2020 }\end{array}$ & $\begin{array}{l}\text { - On 19.1.2016, the } \\
\text { Commission adopted } \\
\text { a proposal for a di- } \\
\text { rective amending the } \\
\text { Council Framework } \\
\text { Decision 2009/315/ } \\
\text { JHA regarding ECRIS, } \\
\text { and on 29.6.2017 - } \\
\text { a complementary } \\
\text { proposal for a regu- } \\
\text { lation to establish } \\
\text { a centralized ECRIS- } \\
\text { TCN system } \\
\text { - the final phase of } \\
\text { trilateral negotiations } \\
\text { between the co-legis- } \\
\text { lators is ongoing } \\
\text { - the Directive and the } \\
\text { Regulation have not } \\
\text { been formally ad- } \\
\text { opted by the Council } \\
\text { and the European } \\
\text { Parliament }\end{array}$ \\
\hline
\end{tabular}

Note: The EU-Lisa agency (European Agency for the Operational Management of large-scale IT Systems at the AFSJ) has been in operation since 2012: prior to the reform it operated Eurodac, SIS II and VIS systems; after the reform, it will be entrusted with the preparation and operational management of the new EES, ETIAS and ECRIS-TCN systems. The Agency will also be responsible for developing interoperability between EU information systems in the field of justice and internal affairs and improving the quality of data available at the Union level, as well as supporting Member States in the implementation of systems at national level.

Source: Own study based on: EC (2016a), Proposal for a Regulation of the European Parliament and of the Council establishing a European Travel Information and Authorisation System (ETIAS) and amending Regulations (EU) No 515/2014, (EU) 2016/399, (EU) 2016/794 and (EU) 2016/1624, Brussels 16.11.2016, COM(2016) 731 final; Regulation (EU) 2017/2226 of the European Parliament and of the Council of 30 November 2017 establishing an Entry/Exit System (EES) to register entry and exit data and refusal of entry data of third-country nationals crossing the external borders of the Member States and determining the conditions for access to the EES for law enforcement purposes, and amending the Convention implementing the Schengen Agreement and Regulations (EC) No 767/2008 and (EU) No 1077/2011, Official Journal of the EU L 327/20, 9.12.2017; EC (2016c), Communication from the Commission to the European Parliament and the Council Stronger and Smarter Information Systems for Borders and Security, Brussels 6.4.2016, COM(2016) 205 final. 
Despite many advantages, one should also remember that the development of the above information systems carry various kinds of dangers - the scale and nature of the data being processed will enable its violation, and that may be dangerous to the fundamental rights of the persons concerned. Therefore, a particular challenge for all EU and national bodies involved in the process of creating a new information infrastructure will be to ensure diligence and high quality of processing data, adequate security regarding access and controlling its use.

The next step taken by the EU to overcome the crisis was to establish cooperation with third countries ${ }^{63}$. The action plan from Valetta (11-12.11.2015) and Bratislava (16.10.2016) provides:

- elimination of the root causes of irregular migration and factors forcing people to leave their places of residence,

- more effective support and organization of legal migration methods,

- increasing the protection of migrants and asylum seekers,

- the fight against smuggling of migrants and using their hard position,

- closer cooperation in the field of return, readmission and reintegration.

To successfully implement both plans in a year:

- 2015:

- a common European list of safe countries has been established ${ }^{64}$,

- an EU action plan on returns has been developed (updated and expanded in 2017),

- diplomatic and financial activities aimed at stabilization of regions of Africa and the Middle East were carried out (e.g. EU regional strategy for Syria and Iraq and ISIS / Daesh threats, extraordinary EU trust fund for Africa, Refugee Assistance Facility in Turkey),

- talks were held with the countries of the Balkan Peninsula and a 17-point action plan was prepared for better management of migrants and refugees' flows on the Western Balkans route, especially in terms of their reception capacity and border management,

- 2016:

- a new partnership framework in the field of migration (June 2016) was outlined - close cooperation with countries of origin and transit (Ethiopia, Mali, Niger, Nigeria, Senegal, Afghanistan, Algeria, Egypt, Libya, Tunisia) to ensure

${ }^{63}$ The activities undertaken are part of the so-called 'Global approach to migration and mobility issues' from 2011. See: EC (2011), The Global Approach to Migration and Mobility, Brussels 18.11.2011, $\operatorname{COM}(2011) 743$ final.

${ }^{64}$ In international law (Geneva Convention) and EU law (directive on asylum procedures), it is recognized that a country is safe if it has a democratic regime and, as a rule and consistently: there is no persecution; no torture, inhuman or degrading treatment or punishment is used; there is no threat of using violence; there is no armed conflict. 
greater effectiveness of returning illegal immigrants from the EU and limit the flow of people by, on the one hand, strengthening the capacity of EU neighbours to protect borders and, on the other, by eliminating the causes of illegal migration,

- an EU-Turkey Statement was agreed (March 2016) - joint actions to improve coordination in the field of migration management along the East Mediterranean route, to end illegal migration from Turkey to the EU and combat crime behavior - from 20.3.2016, migration flows are to take place according to the so-called 1:1 system ${ }^{65}$,

- 2017:

- an agreement was concluded with North African countries, i.e. the Maltese Declaration (February 2017) - joint actions to improve coordination in the field of migration management on the Middle-Mediterranean route in the shape of enhanced EU-Turkey cooperation of $2016^{66}$,

- financial support for humanitarian needs for the Syrian population was continued (EUR 5.6 billion in 2017, EUR 3 billion in 2016),

- 2018:

- cooperation with third countries (mainly from Africa) was strengthened, including EU-Egypt (in the context of the EU-League of Arab States planned for February 2019),

- financial support was continued under the Refugee Facility in Turkey to support refugees from Syria (EUR 3 billion in 2018-2019).

The decisions and actions taken so far by the EU to address the migration and refugee crisis, in consultation with third countries from Europe and outside Europe, are assessed differently. Close cooperation between the EU and the countries of the Balkan Peninsula or Turkey has resulted in, above all, limiting the influx of migrants and improving the living conditions of people staying in refugee camps. However, the controversy over the EU-Turkey Statement ${ }^{67}$ raises doubts and questions about whether the agreement survives, and whether this formula of cooperation can, and

65 The parties have committed themselves to controlling the influx of refugees and enabling people in need of international protection to reach Europe in a safe and legal manner.

${ }^{66}$ For more see: European Council (2017), Informal meeting of EU heads of state or government, https://www.consilium.europa.eu/en/meetings/european-council/2017/02/03/ [Accessed: 10.08.2018].

67 The EU-Turkey agreement is not perfect. Apart from a number of questions related to its (un) certain implementation, including the ability to act effectively, the tense relations between the Athens and Ankara are deemed problematic. International organizations dealing with the protection of human rights (including UNHCR, Norwegian Refugee Council, Amnesty International, and Human Rights Watch) have reported serious concerns regarding the content of the EU-Turkey agreement. They perceive it as a source of political dependence of the EU on the Turkish President - Recep Tayyip Erdoğan, who rules the country in an increasingly autocratic style, and the pursuit of the EU and Turkey's particular interests. The most controversial are: 


\section{SM̂PP}

should, serve as a model for other such projects in the region of Africa and the Middle East. The situation is similar in the case of EU development policy, which aims to eliminate sources of crisis outside Europe - to date, despite the involvement of EU forces and resources to help countries of origin and transit, it has not been significantly closer to achieving this goal.

\section{Conclusions}

In 1995, the United Nations High Commissioner for Refugees - Sadako Ogata, stated that the reason for the inability to solve the problem of refugees is, among others, the lack of international solidarity with regard to the problem of refugees and involuntary migrations ${ }^{68}$. She also pointed out that for social, economic or political reasons, countries avoid taking responsibility for refugees, treating the phenomenon as a threat to their own interests and security. Unfortunately, the current migration and refugee crisis has shown how fragile and declarative in nature are the assurances of the need to respect international law, the principles of human rights and humanitarian norms.

On the basis of the research, it can be stated that in recent years the EU has experienced several crises that have damaged its image as well as its convictions about European unity and solidarity. The migration and refugee crisis, which the EU has been struggling with since 2015, undermined one of the fundamental EU pillars, namely the free movement of people within the Schengen area. What seemed like a simplification and opportunity for more than a quarter of a century has suddenly become a threat. In the face of the inflow of immigrants from the restless regions of the world, the EU has found itself in a difficult position because, on the one hand, it defends the basic values guiding its functioning, but on the other hand, it has to ensure security for its citizens and take effective measures to protect its external borders.

The current migration, visa and asylum policies, as well as the solutions adopted within them, have proven insufficient in the face of sudden, growing, uncontrolled migration flows. The way the crisis has evolved clearly showed that neither the EU nor

- recognition of Turkey as a 'safe third country' because it applies the Geneva Convention of 1951 to a limited extent and does not provide the possibility of granting refugee status to persons from non-European countries;

- direct returning of migrants at sea;

- visa liberalization to the EU;

- the prospect of accelerating accession negotiations, which creates divisions within the EU - according to many Member States, Turkey does not meet the so-called Copenhagen criteria, including above all the political ones;

- ability to effectively use EU financial support.

${ }^{68}$ Amnesty International (1997), Refugees: Human rights have no borders, https://www.amnesty.org/ en/documents/act34/003/1997/en/ [Accessed: 15.08.2018]. 
any of the Member States is 'prepared' to meet such a challenge. Moreover, in the face of the rapidly growing number of immigrants (including refugees), it is obvious that without a joint decision and coordinated action, no European state can solve this problem alone. In retrospect, it can be seen that mass immigration has caused a serious crisis - both in the EU and of the EU itself. The lack of common ground in the context of 'crisis management' has created considerable discrepancies between EU institutions and Member States and between the Member States themselves, revealing their lack of respect for the fundamental values of the idea of a united Europe under the EU banner, i.e. unity, solidarity and mutual responsibility.

The crisis showed how different the approaches to its management can be: on the one hand, 'European openness', on the other, 'European security'. As a result of the lack of the ability to develop commonly accepted and implementable solutions at the supranational level, a discussion began about which countries are 'open' and which are 'closed' to migrants and refugees and their problems; which present an 'open door' policy, and which push proposals aimed at fighting the crisis 'at the source'. All this causes considerable difficulties in building a common EU policy with regard to the issue of refugees.

\section{References}

Abé N., Amann M., Gude H., Müller P., Neukirch R., Pfister R., Schmid B., Schult Ch., Stark H., Wiedmann-Schmidt W. (2015), Herzdame, 'Der Spiegel', 19 September, www.spiegel.de [Accessed: 15.08.2018].

Amnesty International (2018), Reforma systemu azylowego UE: szansa na realne zmiany dla uchodźców, https://amnesty.org.pl/reforma-systemu-azylowego-ue-szansa-na-realne-zmianydla-uchodzcow/ [Accessed: 15.08.2018].

Amnesty International (1997), Refugees: Human rights have no borders, https://www.amnesty. org/en/documents/act34/003/1997/en/ [Accessed: 15.08.2018].

Bielecki T. (2015), Imigracja dzieli Unię - 'nowa' Europa nie chce obowiązkowych kwot uchodźców, „Wyborcza", 16 June, www.wyborcza.pl [Accessed: 15.08.2018].

Böhm W. (2011), Ein Rückbau der EU in die nationale Beschaulichkeit, 'Die Presse', 12 May, www. diepresse.com [Accessed: 15.08.2018].

Brady H. (2012), Saving Schengen. How to protect passport-free travel in Europe, https://www. opensocietyfoundations.org/sites/default/files/2012-01_Saving\%2520Schengen.pdf [Accessed: 15.08.2018].

Burki R. (2011), Schengen: Back to the nation oasis, 'Die Presse', 13 May, www.diepresse.com [Accessed: 15.08.2018].

Collett E., Le Coz C. (2018), After the Storm: Learning from the EU response to the migration crisis, Brussels: Migration Policy Institute Europe.

Cymbranowicz K. (2017), Europa (bez)granic - w poszukiwaniu rozwiązania kryzysu migracyjnego w Unii Europejskiej, in: Tendera-Właszczuk, H., Bąba, W., Zajączkowska, M. (eds.), Nowe perspektywy integracji europejskiej w obliczu wyzwań i zagrożeń, Warszawa: Difin, pp. 48-79. 


\section{SM̂PP}

Czesi rozczarowani postawą Polski. Prasa: Polska zawiodła. Grupa Wyszehradzka się rozpadła (2015), „wPolityce.pl”, 23 September, www.wpolityce.pl [Accessed: 15.08.2018].

Delcker J. (2016), The phrase that haunts Angela Merkel. A year on and the German leader hasn't recovered from 'we can do it', 'Politico', 19 August, https://www.politico.eu/ [Accessed: 15.08.2018]..

Diez G. (2015), Ja, wir schaffen das, 'Der Spiegel', 25 October, www.spiegel.de [Accessed: 15.08.2018].

Eastern Europe's Short Memory (2015), 'The New York Times', 15 September, www.nytimes.com [Accessed: 15.08.2018].

EC (2017a), President Jean-Claude Juncker's State of the Union Address 2017, http://europa.eu/ rapid/press-release_SPEECH-17-3165_en.htm [Accessed: 10.08.2018].

EC (2017b), Standard Eurobarometer 87 - Spring 2017. Public opinion in the European Union. First results, http://ec.europa.eu/commfrontoffice/publicopinionmobile/index.cfm/Survey/getSurveyDetail/surveyKy/2142 [Accessed: 10.02.2018].

EC (2017c), Eurobarometer Flash 450. The future of Europe - views from outside the EU, http:// ec.europa.eu/commfrontoffice/publicopinion/index.cfm/Survey/getSurveyDetail/instruments/ FLASH/surveyKy/2141 [Accessed: 10.02.2018].

EC (2016a), Proposal for a Regulation of the European Parliament and of the Council establishing a European Travel Information and Authorisation System (ETIAS) and amending Regulations (EU) No 515/2014, (EU) 2016/399, (EU) 2016/794 and (EU) 2016/1624, Brussels 16.11.2016, $\operatorname{COM}(2016) 731$ final.

EC (2016b), Proposal for a Regulation of the European Parliament and of the Council establishing the criteria and mechanisms for determining the Member State responsible for examining an application for international protection lodged in one of the Member States by a third-country national or a stateless person (recast), Brussels 4.5.2016, COM(2016) 270 final.

EC (2016c), Communication from the Commission to the European Parliament and the Council Stronger and Smarter Information Systems for Borders and Security, Brussels 6.4.2016, $\operatorname{COM}(2016) 205$ final.

EC (2016d), Back to Schengen - a Roadmap, Brussels 4.3.2016, COM(2016) 120 final.

EC (2015a), EU Action Plan against migrant smuggling (2015-2020), Brussels 27.5.2015, $\operatorname{COM}(2015) 285$ final.

EC (2015b), A European Agenda on Migration, Brussels 13.5.2015, COM(2015) 240 final.

EC (2015c), The European Agenda on Security, Brussels 28.4.2015, COM(2015) 185 final.

EC (2011), The Global Approach to Migration and Mobility, Brussels 18.11.2011, COM(2011) 743 final.

Europa przemówiła. Niemal 80\% Europejczyków chce lepszej kontroli granic (2018), „Do Rzeczy”, 29 March, www.dorzeczy.pl [Accessed: 15.08.2018].

European Commission - Press release (2013), Smart borders: enhancing mobility and security, http://europa.eu/rapid/press-release_IP-13-162_en.htm [Accessed: 10.08.2018].

European Council (2017), Informal meeting of EU heads of state or government, https://www.consilium.europa.eu/en/meetings/european-council/2017/02/03/ [Accessed: 10.08.2018].

European Court of Auditors (2017), EU response to the refugee crisis: the 'hotspot' approach, http://publications.europa.eu/webpub/eca/special-reports/refugee-crisis-hotspots-06-2017/en/ [Accessed: 4.08.2018]. 
Feher M., Thomas A. (2015), Austria Toughens Controls Amid European Migrant Crisis, 'The Wall Street Journal', 31 August, www.wsj.com [Accessed: 15.08.2018].

Frontex data, https://frontex.europa.eu/along-eu-borders/migratory-routes/ [Accessed: 20.11.2018]. Fundacja Századvég (2018), http://project28.eu/migration-terrorism-2018/ [Accessed: 10.08.2018]. GMF (2014), Transatlantic Trends: Mobility, Migration and Integration. Key Findings from 2014 and Selected Highlights from Transatlantic Trends and Transatlantic Trends: Immigration 2008-2013, http://www.gmfus.org/publications/transatlantic-trends-mobility-migration-andintegration [Accessed: 10.08.2018].

Kapiszewski J., Cedro M. (2018), Twierdza Europa. Polityka migracyjna dzieli Stary Kontynent, choć liczba imigrantów spada, „Dziennik Gazeta Prawna”, 6 July, www.gazetaprawna.pl [Accessed: 15.08.2018].

Kopeć J., Korzeniowska K. (2018), Spada liczba osób nielegalnie przekraczających granice Unii. Ale za jaką cenę?, „Wyborcza”, 28 February, www.wyborcza.pl [Accessed: 15.08.2018].

Krogstad J. M. (2015), What Americans, Europeans think of immigrant, 'Pew Research Center', 24 September, www.pewglobal.org [Accessed: 15.08.2018].

Maldini P., Takahashi M. (2017), Refugee Crisis and the European Union: Do the Failed Migration and Asylum Policies Indicate a Political and Structural Crisis of European Integration?, 'Communication Management Review', No. 2, pp. 54-72.

Nakonieczna-Bartosiewicz J. (2016), Migracyjny szok czy migracyjna histeria?, in: Kuźniar, R. (ed.), Rocznik Strategiczny 2015/16. Przegląd sytuacji politycznej, gospodarczej i wojskowej w środowisku międzynarodowym Polski, Warszawa: Wydawnictwo Naukowe SCHOLAR, pp. 369-384.

Nolan D. (2015), Refugee crisis: EU divided as Hungary attacks migrant quota as 'unrealisable and nonsense', 'The Telegraph', 23 September, www.telegraph.co.uk [Accessed: 15.08.2018].

Nougayrede N. (2015), Angela Merkel is right: the migration crisis will define this decade, 'The Guardian', 21 August, www.theguardian.com [Accessed: 15.08.2018].

Pop V., Norman L., Fidler S. (2015), EU Leaders Agree to Modest Measures for Handling Growing Migrant Crisis, 'The Wall Street Journal', 23 September, www.wsj.com [Accessed: 15.08.2018]. Potyrała A. (2016), Środkowoeuropejska koalicja niechętnych wobec kryzysu migracyjnego 20152016, „Środkowoeuropejskie Studia Polityczne”, No. 1, pp. 25-50.

Poushter J. (2016), European opinions of the refugee crisis in 5 charts, 'Pew Research Center', 16 September, www. pewglobal.org [Accessed: 15.08.2018].

Poushter J. (2015), Refugees stream into Europe, where they are not welcomed with open arms, 'Pew Research Center', 24 April, www.pewglobal.org [Accessed: 15.08.2018].

Przyjmowanie imigrantów dzieli Europę. Jest oficjalny sprzeciw (2015), „Wprost”, 10 September, www.wprost.pl [Accessed: 15.08.2018].

Reitano T., Adal L., Shaw M. (2014), Smuggled Futures: The dangerous path of the migrant from Africa to Europe, The Global Initiative against Transnational Organized Crime, http://www.integrazionemigranti.gov.it/Attualita/Notizie/Documents/Global\%20Initiative.pdf [Accessed: 4.08.2018].

Regulation (EU) 2017/2226 of the European Parliament and of the Council of 30 November 2017 establishing an Entry/Exit System (EES) to register entry and exit data and refusal of entry data of third-country nationals crossing the external borders of the Member States and determining the conditions for access to the EES for law enforcement purposes, and amending the Convention implementing the Schengen Agreement and Regulations (EC) No 767/2008 and (EU) No 1077/2011, Official Journal of the EU L 327/20, 9.12.2017. 


\section{SM̂PP}

Regulation (EU) 2017/458 of the European Parliament and of the Council of 15 March 2017 amending Regulation (EU) 2016/399 as regards the reinforcement of checks against relevant databases at external borders, Official Journal of the EU L 74/1, 18.3.2017.

Regulation (EU) 2016/1624 of the European Parliament and of the Council of 14 September 2016 on the European Border and Coast Guard and amending Regulation (EU) 2016/399 of the European Parliament and of the Council and repealing Regulation (EC) No 863/2007 of the European Parliament and of the Council, Council Regulation (EC) No 2007/2004 and Council Decision 2005/267/EC, Official Journal of the EU L 251/1, 16.9.2016.

Regulation (EC) No 2007/2004 and Council Decision 2005/267/EC, Official Journal of the EU L 251/1, 16.9.2016.

Sasnal P. (2016), Exodus z Syrii. Migranci i uchodźcy z Bliskiego Wschodu, in: Kuźniar, R. (ed.), Rocznik Strategiczny 2015/16. Przegląd sytuacji politycznej, gospodarczej i wojskowej w środowisku międzynarodowym Polski, Warszawa: Wydawnictwo Naukowe SCHOLAR, pp. 336-356.

Słojewska A. (2018), Imigranci znów dzielą Unię, „Rzeczpospolita”, 25 June, www.rzeczpospolita. pl [Accessed: 15.08.2018].

'Szantaż', 'primaaprilisowy żart' i 'atak na suwerenność'. Grupa V4 ostro o planie KE (2016), http://www.tvn24.pl/wiadomosci-ze-swiata,2/polska-i-wegryostro-krytykuja-propozycjenowej-polityki-azylowej-ue,640973.html [Accessed: 4.08.2018].

Szczepanik M. (2015), Mare Nostrum, „Biuletyn Migracyjny” 51, pp. 2-3.

Szymańska J. (2018a), Scentralizowane systemy informacyjne w zarządzaniu procesami migracyjnymi w UE, „Biuletyn PISM” 122(1695), http://www.pism.pl/publikacje/biuletyn/nr-122-1695 [Accessed: 10.08.2018].

Szymańska J. (2018b), Kontrole na granicach wewnętrznych strefy Schengen: wyjątki stają się regułą, „Biuletyn PISM” 17(1590), https://www.pism.pl/publikacje/biuletyn/nr-17-1590 [Accessed: 10.08.2018].

Szymańska J. (2016), Międzyrządowość vs. ponadnarodowość w polityce migracyjnej i obszarze spraw wewnętrznych Unii Europejskiej, in: Grosse, T. G. (ed.), Polityki europejskie w dobie kryzysu, Warszawa: Wydawnictwo Naukowe SCHOLAR, pp. 253-274.

Tendera-Właszczuk H. (2017), Kryzys migracyjny zagrożeniem dla zasad i podstawowych wartości Unii Europejskiej, in: Tendera-Właszczuk, H., Bąba, W., Zajączkowska, M. (eds.), Nowe perspektywy integracji europejskiej w obliczu wyzwań i zagrożeń, Warszawa: Difin, pp. 32-47.

Valls ostrzega przed rosnącą liczbą uchodźców (2015), https://euroislam.pl/valls-ostrzega-przedrosnaca-liczba-uchodzcow/ [Accessed: 15.08.2018].

United Nations, Convention relating to the Status of Refugees. Geneva. 28 July 1951, https:// treaties.un.org/doc/Treaties/1954/04/19540422\%2000-23\%20AM/Ch_V_2p.pdf [Accessed: 15.08.2018].

Wike R., Stokes B., Simmons K. (2016), Europeans Fear Wave of Refugees Will Mean More Terrorism, Fewer Jobs, 'Pew Research Center', 11 July, www.pewglobal.org [Accessed: 15.08.2018]. Wojtaszczyk K. A. (2017), Kryzys uchodźczy jako wyzwanie dla przyszłości projektu integracyjnego w Europie, in: Wojtaszczyk, K. A., Szymańska, J. (eds.), Uchodźcy w Europie. Uwarunkowania. Istota. Następstwa, Warszawa: Oficyna Wydawnicza ASPRA-JR, pp. 194-207.

World Economic Forum (2016), The Global Risks Report 2016. 11th Edition, http://www3.weforum.org/docs/GRR/WEF_GRR16.pdf [Accessed: 15.08.2018].

Wyligała H. (2016), Strategiczny rozwój narzędzi polityki migracyjnej UE w obliczu kryzysu migracyjnego, „Rocznik Bezpieczeństwa Międzynarodowego” 10(2), pp. 163-189. 